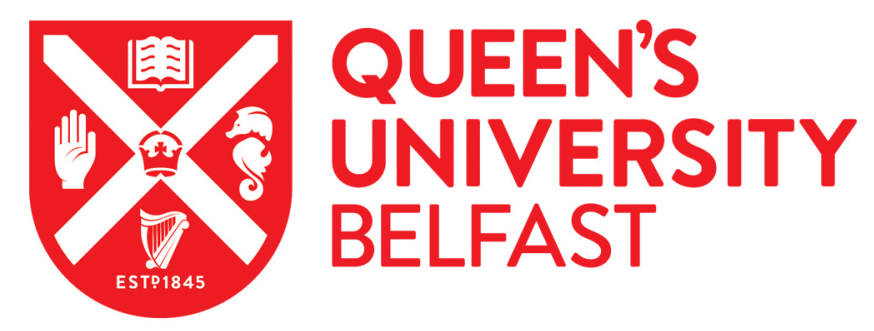

\title{
Determinants of academic cheating behavior: The future for accountancy in Ireland
}

Ballantine, J. A., McCourt Larres, P., \& Mulgrew, M. (2014). Determinants of academic cheating behavior: The future for accountancy in Ireland. Accounting Forum, 38(1), 55-66. https://doi.org/10.1016/j.accfor.2013.08.002

\author{
Published in: \\ Accounting Forum
}

Document Version:

Peer reviewed version

Queen's University Belfast - Research Portal:

Link to publication record in Queen's University Belfast Research Portal

Publisher rights

(c) 2015 Elsevier Ltd. This manuscript version is made available under the CC-BY-NC-ND 4.0 license http://creativecommons.org/licenses/bync-nd/4.0/ which permits distribution and reproduction for non-commercial purposes, provided the author and source are cited.

\section{General rights}

Copyright for the publications made accessible via the Queen's University Belfast Research Portal is retained by the author(s) and / or other copyright owners and it is a condition of accessing these publications that users recognise and abide by the legal requirements associated with these rights.

Take down policy

The Research Portal is Queen's institutional repository that provides access to Queen's research output. Every effort has been made to ensure that content in the Research Portal does not infringe any person's rights, or applicable UK laws. If you discover content in the Research Portal that you believe breaches copyright or violates any law, please contact openaccess@qub.ac.uk. 


\title{
Determinants of classroom cheating: the future for accountancy in Ireland
}

\author{
J.A. Ballantine ${ }^{\mathrm{a}^{*}}$, P. McCourt Larres ${ }^{\mathrm{b}}$ and M. Mulgrew ${ }^{\mathrm{c}}$ \\ ${ }^{a}$ Department of Accounting, Room 03C23, University of Ulster, Jordanstown campus, Shore \\ Road, Newtownabbey, Co. Antrim, BT37 0QB \\ Belfast, BT7 1NN \\ ${ }^{\mathrm{c}}$ DCU Business School, Dublin City University, Dublin 9, Ireland \\ bSchool of Management and Economics, Queen's University, Belfast
}

This paper considers the potential for improving the reputation of the Irish accountancy profession by exploring undergraduate accounting students' intolerance of academic cheating as a predictor of future attitudes to unethical workplace practices. The study reports that females are significantly less tolerant of cheating than males. Further, with regard to ethical ideology, idealism was found to have a significant positive association with intolerance of cheating while relativism reported no association. It is anticipated that the growing admission of women to membership together with educational intervention to influence idealism may improve ethical attitudes and help restore the profession's reputation.

Keywords: Irish accountancy profession; cheating behavior; gender; idealism; relativism 


\section{Introduction}

The basic premise of efficient capital market investment is that the financial information on which investment decisions are made is reliable. A crucial factor impinging upon reliability is the honesty and integrity of those involved in financial statement preparation. However, in recent years public confidence in financial reporting has been undermined by a series of high profile corporate scandals which have exposed extremely dishonest financial practices. There is little doubt that these major financial scandals have damaged the reputation of the accounting profession. To address the problem, accounting regulators have issued rigorous and far-reaching legislation (for example the Sarbanes Oxley Act 2002 in the US) and established dedicated regulatory bodies such as the Public Company Accounting Oversight Board (PCAOB) in the US, the Monitoring Committee of the Financial Reporting Council in the UK and the Irish Auditing and Accounting Standards Authority (IAASA).

One country which has seen its fair share of unethical business practices among accountants at a very high level, particularly in the banking sector ${ }^{1}$, is Ireland. As a result, the reputation of accountants in this small island has been damaged. Indeed recently, in an open letter to the membership, the president of Chartered Accountants Ireland (CAI) commented that, following recent financial scandals affecting the profession, restoring its reputation was the first and most crucial of the five strategic objectives that the CAI's Council set itself over a 5 year period from 2012. Set against the backdrop of what the CAI president referred to as the biggest and longest recession in living memory, it is hardly surprising that the Irish public have taken exception to the fact that they are expected to make considerable economic and financial sacrifices while news emerges that wealthy accountants have been engaging in dubious self-serving financial transactions. With the importance of this issue in mind, the current study assesses the prospects for restoring public confidence in

\footnotetext{
${ }^{1}$ See for example, Ryan (2011) which discusses the case of Anglo-Irish Bank.
} 
the Irish accounting profession by considering the ethical judgment of future accounting professionals as measured by undergraduate accounting students' intolerance of academic cheating. This approach is consistent with that of Allmon, Page and Robert (2000) who suggested that attitudes to academic cheating are an indicator of future attitudes to unethical business practices. In other words, what students deem acceptable behavior in the classroom impacts upon their expectations of what is acceptable professionally (Nonis \& Swift, 2001).

By using undergraduate accounting students' intolerance of academic cheating to predict Irish accountants' future ethical judgment, the current study also addresses a deficiency in the literature highlighted by Pierce and Sweeney (2010) in their study of ethical decision making among Irish trainee accountants. They concluded that greater priority should be given to ethical decision making by accounting educators, researchers and practitioners. The current study's focus on intolerance of academic cheating addresses Pierce and Sweeney's (2010) suggestion with respect to one particular aspect of ethical decision making, namely ethical judgment.

The current study adopts a multi-campus approach and considers the variables which may influence Irish accounting students' intolerance of cheating behavior. It explores three possible determinants of intolerance of cheating behavior, namely gender, idealism and relativism: the latter two being constructs of ethical ideology. In so doing, it sheds light on why some individuals may be more intolerant of academic cheating than others and considers the implications of this for restoring confidence in the Irish accountancy profession.

The results of the study provide contemporary evidence that both gender and idealism are significantly associated with intolerance of cheating behavior, with females and idealists displaying greater levels of intolerance. However, the other construct of ideology, namely relativism, was found to have no such association. Accordingly, it could be concluded from these findings that influencing idealism among accounting students could make a positive 
contribution to improving ethical attitudes in the classroom and, thereafter, in the workplace. Furthermore, the finding that female accounting students are more intolerant of cheating than their male counterparts augurs well for accountancy in Ireland in thatfemale representation in the profession has risen in recent years (Financial Reporting Council, 2013). Itis anticipated thatthis gender trend together with educational intervention to influence levels of idealism could result in an overall improvement in ethical judgment which may go some way to restore integrity to the profession.

The remainder of the paper is structured as follows. First, a literature review presents a comprehensive consideration of research in the area. Secondly, the research method applied to the study is set out. Thirdly, the results of the tests undertaken are analyzed and discussed. Finally, conclusions are discussed, limitations of the study considered and further work identified.

\section{Literature Review}

\subsection{Cheating in an academic context}

Cheating is defined as acting dishonestly or unfairly to gain an advantage (Oxford English Dictionary). When applied to an academic environment, this definition provides students with a range of opportunities to engage in cheating behavior. A review of the literature identifies a number of examples of behavior which constitute cheating. These include, for example: the use of unauthorized materials in exams or assignments; fabricating information, references or results; intentional plagiarism; providing false excuses for missed exams; and facilitating or assisting other students to commit a dishonest academic act (see for example, McCabe \& Treviño, 1993; Pratt \& McLaughlin, 1989). 
In one of the earliest US studies to consider academic cheating Bowers (1964) drew on a large sample from a number of campuses and reported that business students engaged in various forms of academic dishonesty (including turning in work done by another and plagiarism) and that 'honor codes' were associated with lower levels of cheating. A number of similar multi-campus studies followed that of Bowers (1964). For example, McCabe and Treviño (1993) reported that peer behavior had the most significant relationship with student cheating and that lower levels of cheating were associated with the existence of an 'honor code'. Collecting data across the same campuses as Bowers (1964), McCabe and Bowers (1994) reported an increase in cheating among male undergraduate college students between 1963 and 1991. More recently, McCabe, Ingram, and Dato-on (2006), using a large data set from the US and Canada, found that graduate business students cheat more than their nonbusiness peers and that cheating was most significantly associated with perceived peer behavior.

Whilst a substantial body of research into academic dishonesty has focused on North American institutions, some similar work has been conducted elsewhere. For example, in the UK, Franklyn-Stokes and Newstead (1995) reported high levels of cheating and Newstead, Franklin-Stokes, and Armstead (1996) found that less able, less intrinsically motivated younger male students tended to cheat more. These findings were confirmed in later UK based work by Norton, Tilley, Newstead and Franklyn-Stokes (2001). More recently, Kidwell and Kent (2008) considered attitudes to various cheating behavior among Australian students studying on campus and via distance learning. They reported that, while age and gender were significant influences on cheating behavior, mode of study (namely, on campus versus distance learning) was more significant.

In an Irish context, some limited research has focused on one aspect of cheating behavior, namely plagiarism. Ledwith and Risquez (2008) explored the effects of introducing 
the anti-plagiarism software tool Turnitin to 197 first year Irish engineering students. The findings of the study suggested that students were generally positive about the use of the software, making them more aware of the originality of their own work. A significant reduction in internet plagiarism as a result of the use of Turnitin was also reported. More recently, Risquez, O’Dwyer and Ledwith (2011) reported that an online plagiarism tutorial enabled entrepreneurship students to better recognize and avoid plagiarism. However, the authors argued that more than one prevention tutorial may be required to substantially change views related to engagement in plagiarism.

\subsection{Gender}

Of all the factors thought to predict unethical behavior both in the classroom and in the workplace, gender is the determinant variable most frequently reported. However the results of this empirical work have been far from consistent. A number of these studies has concluded that gender has a significant impact in ethical decision making and that men are more likely to become involved in unethical behavior than women (see for example Ameen, Guffey and McMillan, 1996; Beu, Buckley \& Harvey, 2003; Pierce \& Sweeney, 2010). Terpstra, Rozelle and Robinson (1993) suggested that, because men tend to be more competitive, the finding that competitive individuals exhibit a predilection for unethical behavior provides additional support for a difference between the genders. In a recent study which focuses on Irish trainee accountants, Pierce and Sweeney (2010) investigated gender differences in relation to ethical judgment, intention, intensity and culture. With respect to ethical judgment, the subject of the current study, they reported that Irish female trainee accountants demonstrated higher ethical judgment than their male counterparts in relation to all four audit scenarios investigated. However, the findings were not conclusive in that these differences were significant in respect of only one scenario. 
Conversely, a number of studies have found no relationship between gender and ethical behavior (see for example, Davis \& Welton, 1991; Radtke, 2000; Sikula \& Costa, 1994; Stanga and Turpen, 1991). This body of research reports gender equality in ethical judgment with respect to, for example, accounting students (Stanga and Turpen, 1991), college business students (Davis \& Welton, 1991), management undergraduates across three years of study (Sikula \& Costa, 1994) and practicing accountants (Radtke, 2000).

The lack of consensus across these gender ethics studies reflects the contrasting views of the two major theories which underpin the relationship between gender and moral judgment, namely gender socialization theory and structural theory. On the one hand, gender socialization theory contends that gender identity, established at an early age, results in men and women bringing different ethical values to bear on their academic or workplace ethical behavior and, as a consequence, results in them making different ethical decisions (Betz, O’Connell \& Shepard, 1989). This thesis is consistent with Gilligan's (1982) 'ethic of caring' in which she identified a compassionate dimension present only in female ethical decision making. The result, according to Gilligan (1982), is that women are more ethical than men. On the other hand, a contrast in gender perspective is offered by the structural approach which suggests that different values which may have existed between the sexes in their early years gradually disappear as men and women are subject to similar education and training programs, work environments and reward structures (Betz et al., 1989). Applying the structural theory specifically to accounting students, Ameen et al., (1996) concluded that 'the structural approach predicts that men and women...training for a particular occupation will exhibit the same ethical priorities' (p.593).

Adopting the basic premise that ethical judgment in the classroom predicts future ethical judgment in a professional setting, several studies have tested these alternative gender theories on the ethical judgment of business and accounting students. One of the earliest of 
these studies was carried out by Betz et al. (1989) who, after presenting business students with a number of open-ended questions pertaining to their career goals, reported that females demonstrated greater ethical judgment than males, providing evidence to support the gender socialization theory. However, in a similar study carried out on accounting students around the same time, Stanga and Turpen (1991) found no evidence of gender difference in ethical judgment and concluded, in support of the structural approach, that 'behavioral differences that once existed between the sexes now seem to be rapidly disappearing' (Stanga and Turpen, 1991, p.746). Continuing the investigation of gender differences among accounting students, Ameen et al. (1996) reported results that contrasted with those of Stanga and Turpen (1991) but supported the work of Betz. et al. (1989) namely that 'the gender socialization approach dominates the structural approach' (Ameen, et al., 1996, p.591).

The gender differences reported by Ameen et al. (1996) were based on a survey instrument containing examples of questionable academic activities with which the students were familiar rather than real-world scenarios such as those adopted by Stanga and Turpen (1991). Ameen et al.'s approach mirrored that of Forrest and Pritchett (1990) who recommended that the ethical judgment of business students is best assessed using classroom activities with which they are familiar i.e. 'a temporal reality' rather than presenting them with unfamiliar real-world business scenarios which create 'a remote, unexperienced situation' (Forrest and Pritchett, 1990, p.118). Forrest and Pritchett (1990) operationalised the students' temporal reality by developing the Cheating Behaviors Questionnaire (CBQ) containing a number of questionable classroom behaviors based on issues which business executives had highlighted as being unethical. For example, claiming credit for someone else's work, identified as an unethical practice by business executives (Ferrell and Weaver, 1978) was included in the CBQ as items such as plagiarizing published material and having someone else complete an assignment. Accordingly, by employing an instrument such as the 
CBQ, students' evaluation of the acceptability of cheating in the classroom represents their evaluation of what is acceptable in a business context (Forrest and Pritchett, 1990).

The seminal gender ethics studies carried out by Stanga and Turpen (1991) and Ameen et al. (1996) were influenced by the increasing representation of females in the accounting profession in the US. This trend has also been a feature of the profession in Ireland in recent years with statistics currently indicating an equal gender split among students (i.e. females $(50 \%)$ and males (50\%)) registering as Irish chartered accountancy students in 2012 (Financial Reporting Council, 2013). Accordingly, the current study aims to contribute to and update the extant literature on gender ethics by providing a contemporary perspective on the issue within an Irish accounting context. To this end, the following hypothesis is tested:

Hypothesis 1: There is no association between undergraduate accounting students' intolerance of cheating behavior and their gender.

\subsection{Ethical ideology}

Ethical ideology is defined as one's approach to ethical decision making and is considered to be a determinant of ethical judgment (Forsyth, 1980). According to Schlenker and Forsyth (1977), one's ethical ideology comprises two scales, namely idealism and relativism. An individual's levels of idealism and relativism are assessed using the Ethics Position Questionnaire (EPQ) developed by Forsyth (1980). Idealism is concerned with the extent to which an individual has a genuine concern for the welfare of others and for taking only those actions which do not harm others (Forsyth, 1992). A high level of idealism suggests a tendency to assume that good consequences ensue from the proper action being taken. Alternatively, a low level of idealism acknowledges that bad as well as good 
consequences may follow an action. Relativism is associated with the acceptance of moral rules. High levels of relativism are associated with individuals who reject universal moral rules while those who adopt a less relativistic position stress the importance of following universal moral principles when making an ethical decision.

Schlenker and Forsyth (1977) developed their ethical construct of idealism and relativism from the classical philosophies of deontology, teleology and ethical skepticism. Deontology applies pre-defined rules or duties to determining the choice of action in an ethical dilemma. In deontological ethics the moral rightness of an action is judged by a characteristic of the action itself rather than the product of the action. The motivation of the agent in performing the action rather than the consequences of the action determine whether it is good or bad. This contrasts markedly with teleological ethics which proposes that moral judgment regarding an action should be based on the consequences that are likely to ensue from the action. The rigid normative position of both these philosophies is, however, rejected in the various branches of ethical skepticism. Ethical skepticism, which includes emotivism, cultural relativism and ethical egoism, completely refutes the notion of following universal rules when faced with a moral dilemma, irrespective of whether the rules are founded on deontological or teleological principles. Indeed, ethical skepticism, on account of its pragmatism, is the preferred ethical philosophy of a number of researchers when faced with the inherent difficulties of applying the rigid normative propositions of both deontology and teleology to resolve ethical dilemmas in a business context (Barnett, Bass and Brown, 1994).

Schlenker and Forsyth (1977), in establishing the scales of idealism and relativism, abandoned the notion of a normative position of rightness entrenched in both deontology and teleology and, instead, considered the differences among all three classical theories with regard to rules-orientation and pragmatism. For example, deontology is associated with high levels of idealism in that both are concerned with the welfare of individuals and treating each 
person ethically irrespective of the potential consequences. Teleology, on the other hand, is allied to the non-idealistic position insofar as both acknowledge that bad as well as good consequences may ensue from an action: the utilitarian aspect of teleology being that positive consequences must outweigh negative. Ethical skepticism, on account of its various branches, is associated with the complete idealism scale from the non-idealistic pure pragmatic perspective through to high levels of idealism (Barnett, Bass and Brown, 1996).

The association between relativism and the classical philosophies is less diverse in that both deontology and teleology are associated with a non-relativistic position. Analogous to the non-relativistic view, they both promote adherence to universal moral principles, teleology's being based on the consequences of an action and deontology's on the intrinsic rightness of an action based on pre-determined rules and duties. However, the various branches of ethical skepticism, on the other hand, espouse a very clear relativistic perspective in that they completely renounce the notion of universal moral rules.

A number of studies have investigated the impact of idealism and relativism on ethical decision making among students. While Chan and Leung (2006) and Forsyth and Berger (1982) found limited association between idealism and relativism on the one hand and ethical decision making on the other, the majority of studies have reported that idealism is more positively and significantly associated with stricter ethical judgment than relativism. For example, Barnett et al. (1994) confirmed the stronger influence of idealism on stricter ethical judgment among US business studies students when presented with a wide range of workbased moral dilemmas. In a later study, again by Barnett et al. (1996), idealism was found to have a stronger impact than relativism on business studies students' intention to report cheating behavior. In more recent work, Sierra and Hyman (2008) also found evidence to suggest that high levels of idealism are associated with efforts to minimize cheating intentions. 
The current study also focuses on the impact of students' ethical ideology, as determined by their levels of relativism and idealism, on their intolerance of classroom cheating behavior, but does so specifically in an Irish accounting context. Given that 'it has been demonstrated that unethical behavior in school can lead to unethical behavior in business' (Granitz and Loewt, 2007, p.293), it is anticipated that the findings of the current study will provide contemporary evidence of how scale-based ethical ideology may impact on the ethical judgment of future accounting professionals at a time when financial institutions in general and the reputation of the modern Irish accountant in particular have been called into question (O’ Carroll, 2010).

Given the foregoing discussion, the following hypotheses are stated for testing:

Hypothesis 2: $\quad$ There is a negative association between accounting undergraduate students' intolerance of cheating behavior and their level of relativism.

Hypothesis 3: $\quad$ There is a positive association between accounting undergraduate students' intolerance of cheating behavior and their level of idealism.

\section{Methodology}

\subsection{Measuring cheating behavior}

The hypotheses developed in the current study were tested using an ordered Logit model, the aim being to understand the relationship between students' intolerance of cheating behavior, gender, relativism and idealism. A multi-campus study was employed. A questionnaire comprising three sections was developed and distributed at three Irish universities. The first section of the questionnaire was designed to illicit general information regarding the respondents. Given the sensitivity of the subject matter and in line with ethics 
policy at the three universities, this section was designed to collect inoffensive background information such as gender and country where pre-university education was obtained.

The second section contained a number of statements pertaining to unethical classroom behavior set out in the Cheating Behaviors Questionnaire (CBQ) developed by Forrest and Pritchett (1990). Following the approach adopted by Forrest and Pritchett (1990), accounting students' ethical judgment in the current study is measured by their attitude to unethical behavior in the classroom rather than presenting them with unfamiliar real-world business case scenarios to compensate for the fact that 'most students lack corporate work experience' (Jones, Hamilton and Ingram, 2007, p.40). Indeed, it is for this reason that the CBQ has been adopted in a number of studies which have gauged ethical judgment among business and accounting students as a predictor of future workplace ethical judgment (see for example Allmon et al., 2000; Jones et al., 2007). The CBQ comprises nine items representing common types of academic cheating behavior, such as cheating in an exam and copying extracts from published articles. Sample statements include, "I believe cheating in an exam is..." and "I believe plagiarizing published articles and submitting them as my own work is...". The CBQ requires respondents to evaluate the ethicality of these classroom cheating behaviors by selecting a position on a Likert-type scale ranging from 1 'always acceptable' through to 5 'always unacceptable'. In terms of moral philosophy, 'always unacceptable', represents the deontological perspective of moral truth wherein cheating, lying and stealing are intrinsically wrong. On the other hand, 'always acceptable' approaches a position of ethical amorality or ethical nihilism, the former contending that common good is served by adopting a position of self-interest (Steiner and Steiner, 2011), the latter denying the existence of any objective moral truth. The tenth statement, namely "I believe that honesty is more important than getting good grades", captures the student's general attitude to classroom cheating. It is also 
answered from a five-point Likert scale with "agree strongly" and "disagree strongly" as anchors.

To ascertain students' intolerance of academic cheating behavior, responses to the ten statements were consolidated into a single metric. This variable, ' $\mathrm{WBEH}_{\mathrm{t}}$ ' is a weighted measure which gauges students' intolerance of academic cheating with higher (lower) values indicating greater (less) intolerance. In order to develop this weighted measure, an analysis of the ten cheating behaviors which comprise the CBQ was first undertaken. Three areas of cheating behavior were identified, namely behavior related to cheating in examinations, behavior related to cheating in continuous assessment activity and other more general aspects of cheating behavior. Following this, a review of the accounting programs in all three institutions involved in the study was undertaken to ascertain the contribution of examinations and continuous assessment to measuring student progress. This review identified the existence of notable consistencies in terms of the weightings attached to examination and continuous assessment marks across the three institutions, with substantially more marks being awarded for the former. Given this, the following weightings were applied. A higher weight (65\%) was attached to the questions in the CBQ pertaining to the potential for cheating in examinations. This reflects the greater contribution which examinations make to the universities' overall degree classification. With respect to continuous assessment, a weight of $25 \%$ was attached to reflect the lower contribution that continuous assessment makes towards the academic progress of the students in the sample. Finally, the remaining $10 \%$ weighting was allocated to the statements in the CBQ which related to more general aspects of cheating behavior. The resulting dependent variable, namely $\mathrm{WBEH}_{\mathrm{t}}$, was then rounded to the nearest integer to facilitate use of the ordered Logit model. 


\subsection{Measuring gender}

A key facet of the current study is to test for the association between students' intolerance of cheating behavior and gender. Accordingly, 'GENDER ${ }_{t}$ ' is included as an independent variable and is set equal to 1 if the student is female and 0 if the student is male.

\subsection{Measuring relativism and idealism}

The final section of the questionnaire was designed to measure respondents' levels of relativism and idealism using the Ethical Position Questionnaire (EPQ). It contains 20 statements, 10 measuring relativism and 10 measuring idealism. Relativism statements include, for example, "Different types of morality cannot be compared to "rightness"" and "There are no ethical principles that are so important that they should be a part of any code of ethics". Statements to measure idealism include: "People should make certain that their actions never intentionally harm another even to a small degree" and "The existence of potential harm to others is always wrong, irrespective of the benefits to be gained". Respondents' agreement or disagreement with the statements was registered using a fivepoint Likert scale ranging from (5) "agree strongly" to (1) "disagree strongly". Consistent with Forsyth (1980), an average of students' responses for each of the ten questions making up the relativism subscale was calculated. The resulting variable, 'REL $L_{t}$ ' provides an average score of students' relativism, namely a measure of the extent to which they accept/reject universal moral rules. Similarly, the average of students' responses for each of the ten questions relating to idealism was computed. The resulting variable, namely ' $I D E A L_{t}$ ' provides an average score of students' idealism, measuring their tendency to assume that good/bad consequences ensue from the action being taken.

\subsection{Model specification}


Hypotheses 1 - 3 are empirically tested using the following ordered Logit model:

$$
\mathrm{WBEH}_{\mathrm{t}}=\alpha_{0}+\alpha_{1} \mathrm{GENDER}_{\mathrm{t}}+\alpha_{2} \mathrm{REL}_{\mathrm{t}}+\alpha_{3} \mathrm{IDEAL}_{\mathrm{t}}+\alpha_{4} \mathrm{PRE}_{\mathrm{EED}}+\alpha_{5} \mathrm{AGE}_{\mathrm{t}}+\alpha_{6} \mathrm{UNI}_{\mathrm{t}}+\varepsilon_{\mathrm{t}}
$$

The above model includes the following control variables: 'PRE-ED ${ }_{\mathrm{t}}$ ' which is set equal to 1 if the student has received the bulk of his/her pre-university education outside Ireland and 0 if otherwise. Secondly, 'AGE ${ }_{t}^{\prime}$ measures the student's age. Finally, given the multiple sources of data used in the study, the variable ' $\mathrm{UNI}_{\mathrm{t}}$ ' is included in the model to capture potential diversity among universities. This variable is coded 1 for students enrolled at University 1, 2 for students enrolled at University 2 and 3 for students enrolled at University 3.

\subsection{Sample and data collection}

All respondents surveyed were enrolled on accounting undergraduate degree programs, each of three years' duration. The universities in the study all enjoy a close relationship with Chartered Accountants Ireland (CAI), wherein their respective degree programs conform to and reflect the content of the CAI's professional training program. In so doing, the three universities provide accounting graduates with generous exemptions from the CAI's professional examinations for qualification as Irish chartered accountants. To this end, there is substantial comparability among the accounting degree programs provided by the three universities, thereby rendering the sample relatively homogeneous in this regard.

Questionnaires were distributed to accounting undergraduate students at the three Irish universities. Prior to distribution, the instructors provided guidance on completing the research instrument and the respondents were informed that the results were to be used for research purposes only. Students were given approximately 20 minutes to complete the questionnaire. Usable questionnaires were obtained for 752 students, representing 295 (39\%) 
from University One, 270 (36\%) from University Two and 187 (25\%) from University Three (representing $76.6 \%$ of students enrolled in accounting programs at the three universities).

Prior to analysis, the data were tested for internal consistency reliability using Cronbach's alpha. The reliability coefficients measured 0.789 for the classroom behavior statements, and 0.71 and 0.830 for the relativism and idealism subscales respectively. Since a reliability coefficient of .70 or higher is considered acceptable in most social science research situations, these results indicate that the internal consistency and reliability of the CBQ and the EPQ, used in this research, are acceptable. Additionally, since the total sample includes respondents from different universities, all variables included in the model were tested for homogeneity. The results showed no significant difference in the variables tested among the three universities surveyed. Therefore, following the approach adopted by Allmon et al. (2000), responses from the three universities were combined to constitute the total sample to be tested.

\section{Analysis and findings}

\subsection{Descriptive statistics}

Table 1 presents statistical information pertaining to the respondents' gender, age and the country in which they received the bulk of their pre-university education. First, Panel A reveals that the total sample is split equally between male and female respondents. When this variable is further analysed according to university, a similar gender balance exists. Secondly, Panel B provides the age profile of the sample, with the overwhelming majority of respondents, both by university and in total, falling into the age range 23 years and younger. Finally, Panel C reports the country in which the respondents received the bulk of their preuniversity education: $93 \%$ being educated in Ireland and the remainder in China. In 
summary, the results set out in Table 1, Panels B and C indicate a high level of homogeneity with respect to the variables contained therein.

Table 1

Descriptive Statistics - Student Demographics

\begin{tabular}{|c|c|c|c|c|c|c|c|c|}
\hline Panel A: Gender & \multicolumn{2}{|c|}{$\begin{array}{l}\text { University } \\
\text { One }\end{array}$} & \multicolumn{2}{|c|}{$\begin{array}{l}\text { University } \\
\text { Two }\end{array}$} & \multicolumn{2}{|c|}{$\begin{array}{c}\text { University } \\
\text { Three }\end{array}$} & \multicolumn{2}{|c|}{ Total } \\
\hline Male & 147 & $50 \%$ & 124 & $46 \%$ & 102 & $55 \%$ & 373 & $50 \%$ \\
\hline Female & 148 & $50 \%$ & 146 & $54 \%$ & 85 & $45 \%$ & 379 & $50 \%$ \\
\hline Total & 295 & $100 \%$ & 270 & $100 \%$ & 187 & $100 \%$ & 752 & $100 \%$ \\
\hline \multicolumn{9}{|l|}{ Panel B: Age } \\
\hline $\begin{array}{l}\text { Up to and including } 23 \text { years } \\
\text { old }\end{array}$ & 289 & $98 \%$ & 238 & $88 \%$ & 174 & $93 \%$ & 701 & $93 \%$ \\
\hline More than 23 years old & 6 & $2 \%$ & 32 & $12 \%$ & 13 & $7 \%$ & 51 & $7 \%$ \\
\hline Total & 295 & $100 \%$ & 270 & $100 \%$ & 187 & $100 \%$ & 752 & $100 \%$ \\
\hline \multicolumn{9}{|l|}{$\begin{array}{l}\text { Panel C: Pre-university } \\
\text { education }\end{array}$} \\
\hline Ireland & 289 & $98 \%$ & 233 & $86 \%$ & 176 & $94 \%$ & 698 & $93 \%$ \\
\hline Outside Ireland & 6 & $2 \%$ & 37 & $14 \%$ & 11 & $6 \%$ & 54 & $7 \%$ \\
\hline Total & 295 & $100 \%$ & 270 & $100 \%$ & 187 & $100 \%$ & 752 & 100 \\
\hline
\end{tabular}


Table 2

Descriptive Statistics of Classroom Behavior Statements

\begin{tabular}{|c|c|c|c|c|c|}
\hline Cheating Behaviors: & $\begin{array}{l}\text { Mean }^{a} \\
\text { Score }\end{array}$ & $\begin{array}{l}\text { Std. } \\
\text { Dev. }\end{array}$ & $1 / 2^{b}$ & $3^{c}$ & $4 / 5^{d}$ \\
\hline \multicolumn{6}{|l|}{ Examinations } \\
\hline $\begin{array}{l}\text { I believe that pretending there is a death in the } \\
\text { family to be excused from sitting an exam is: }\end{array}$ & 4.77 & 0.72 & $3.3 \%$ & $2.7 \%$ & $94.0 \%$ \\
\hline I believe cheating in an exam is: & 4.72 & 0.77 & $4.9 \%$ & $2.8 \%$ & $92.3 \%$ \\
\hline $\begin{array}{l}\text { I believe not reporting a class mate for } \\
\text { cheating in an exam is: }\end{array}$ & 3.31 & 1.19 & $21.3 \%$ & $39 \%$ & $39.8 \%$ \\
\hline \multicolumn{6}{|l|}{ Continuous Assessment } \\
\hline $\begin{array}{l}\text { I believe that getting a class mate to write an } \\
\text { assignment which I submit as my own work is: }\end{array}$ & 4.67 & 0.78 & $4.3 \%$ & $4.0 \%$ & $91.7 \%$ \\
\hline $\begin{array}{l}\text { I believe that plagiarizing published articles } \\
\text { and submitting it as my own work is: }\end{array}$ & 4.49 & 0.87 & $5.2 \%$ & $6.9 \%$ & $87.9 \%$ \\
\hline $\begin{array}{l}\text { I believe that getting a class mate to do the } \\
\text { work on a computer project which I submit as } \\
\text { my own work is: }\end{array}$ & 4.49 & 0.90 & $6.5 \%$ & $5.3 \%$ & $88.2 \%$ \\
\hline $\begin{array}{l}\text { I believe that not telling the lecturer that an } \\
\text { error in calculating my grade gave me a higher } \\
\text { score than I had actually earned is: }\end{array}$ & 3.32 & 1.37 & $32.4 \%$ & $24.9 \%$ & $42.7 \%$ \\
\hline $\begin{array}{l}\text { I believe that using the facilities of my } \\
\text { workplace (e.g. paper, computer etc.) to } \\
\text { complete my assignment/coursework is: }\end{array}$ & 2.11 & 1.20 & $67.4 \%$ & $18.9 \%$ & $13.7 \%$ \\
\hline \multicolumn{6}{|l|}{ General } \\
\hline $\begin{array}{l}\text { I believe that letting another student take the } \\
\text { blame for something that I did wrong is: }\end{array}$ & 4.58 & 0.86 & $5 \%$ & $4.8 \%$ & $90.2 \%$ \\
\hline $\begin{array}{l}\text { I believe that honesty is more important than } \\
\text { getting good grades }{ }^{\text {e: }}\end{array}$ & 3.80 & 1.05 & $12.4 \%{ }^{\mathrm{f}}$ & $18.5 \% \%^{\mathrm{g}}$ & $69.1 \%{ }^{\mathrm{h}}$ \\
\hline
\end{tabular}

a 1="always acceptable"; $2=$ "sometimes acceptable"; $3=$ "neutral"; 4="sometimes unacceptable"; 5="always unacceptable"

${ }^{b}$ The percentage of respondents who chose "always or sometimes acceptable" (i.e. options 1 or 2).

c The percentage of respondents who chose "neutral" (i.e. option 3).

${ }^{d}$ The percentage of respondents who chose "sometimes or always unacceptable" (i.e. options 4 or 5).

e 1="strongly disagree"; $2=$ "disagree"; $3=$ "neutral"; 4="agree"; 5="strongly agree"

${ }^{f}$ The percentage of respondents who chose "strongly disagree or disagree" (i.e. options 1 or 2 ).

${ }^{g}$ The percentage of respondents who chose "neutral" (i.e. option 3).

${ }^{h}$ The percentage of respondents who chose "agree or strongly agree" (i.e. options 4 or 5).

Table 2 provides the means and standard deviations for the ten items of cheating behavior which were measured using a Likert scale ${ }^{2}$. It also classifies students' responses

\footnotetext{
${ }^{2}$ As is to be expected with Likert scale variables, each of the 10 items of cheating behaviour are non-normally distributed.
} 
according to levels of acceptability where a higher score indicates a greater intolerance of the cheating behavior. The highest mean score attained among the behaviors is that attributed to the statement: 'I believe that pretending there is a death in the family to be excused from sitting an exam is', with $94 \%$ of responses indicating that this behavior was unacceptable. This finding is not particularly surprising as lying about family bereavement would be distasteful to most people. At the other end of the scale, the item which received the lowest mean score is 'I believe that using the facilities of one's workplace (e.g. paper, pens, computer etc.) to complete an assignment/coursework is', with $67.4 \%$ of students indicating that this behavior was acceptable. This indicates that a large number of students in the survey were more tolerant of behavior often referred to as organizational deviance (Robinson \& Bennett, 1995). Students' tolerance of organizational deviance may stem from the fact that it appears to be relatively innocuous and commonplace. However, it has a consequence at some level in the organization: a fact which students may not yet have considered. Standard deviations for the variables reported in Table 2 indicate a reasonable degree of variation which might be expected. 
Table 3

Descriptive Statistics $(n=752)$

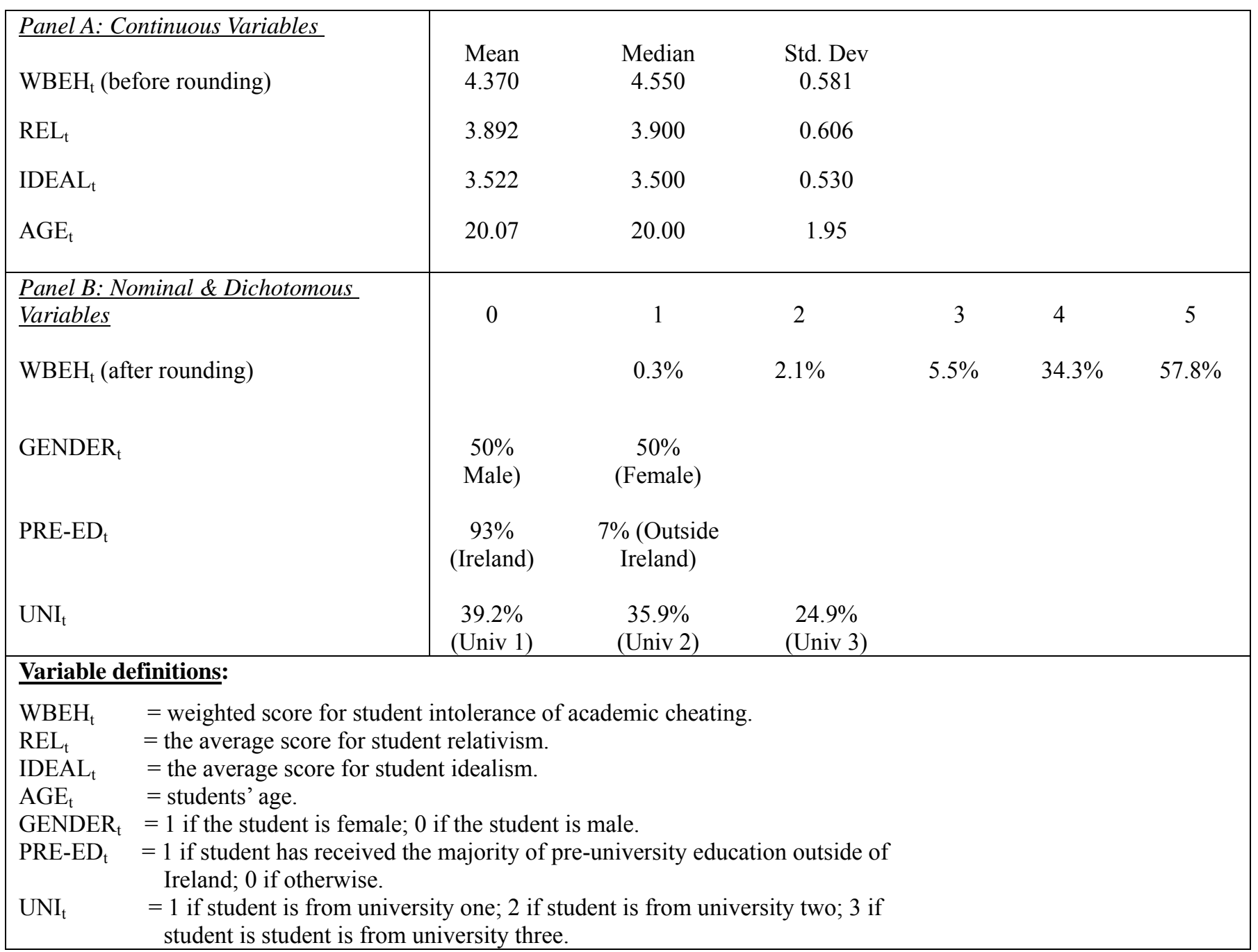

Overall, the relatively high scores reported in Table 2 are encouraging, with 9 out of 10 scores exceeding the mean of 3 . This is especially reassuring in light of the high incidences of cheating reported elsewhere in the literature in accounting/business related areas (see for example, McCabe, Butterfield \& Trevino, 2006; Simkin \& McLeod, 2010). However, complacency with the result must be avoided as there is always room for improvement, particularly with respect to item 10 which summarizes a student's general attitude to classroom cheating behaviors, namely 'I believe that honesty is more important than getting good grades'. It should also be noted at this stage that no student in the sample responded to 
any of the questions with a ' 1 ', indicating a strong tolerance of cheating behavior within the sample.

Table 3 presents descriptive statistics for the variables used in the model applied to the data in this investigation. Consistent with Table 2, results indicate that the average student in the sample appears to be reasonably intolerant of cheating behavior with the mean and median score for $\mathrm{WBEH}_{\mathrm{t}}$ (before rounding) being above $4^{3}$. When $\mathrm{WBEH}_{\mathrm{t}}$ is rounded to the nearest integer for the purposes of empirical modeling, just over half the sample $(50.8 \%)$ fall within the category least tolerant of cheating. Together these results indicate that the students in the sample believe cheating behavior to be generally unacceptable. The mean and median scores for REL ${ }_{t}$ and IDEAL $\mathrm{I}_{\mathrm{t}}$ are between 3 and 4, again with quite a low standard deviation indicating that students in the sample are more inclined to reject universal moral rules and assume good consequences ensue from the actions being taken. In addition, Table 3 also indicates an even split between males and females $\left(\right.$ GENDER $\left._{t}\right)$ in the sample and that the vast majority of the students surveyed have received their pre-university education within Ireland $\left(\mathrm{PRE}-\mathrm{ED}_{\mathrm{t}}\right)$.

\subsection{Multivariate analysis}

To conduct multivariate analysis, an ordered Logit model is applied to the data. This model is most appropriate as the sample data on cheating behavior were initially recorded on a scale of 1 to 5 (see Table 2). An ordered Logit model allows this natural ranking in the dependent variable to be retained for the purposes of estimation and this provides more meaningful insight into the output that such a model yields. Indeed as Greene (2011) notes, given the qualitative nature of dependent variables often measured by questionnaires, such models are

\footnotetext{
${ }^{3}$ It should be noted that the variable ' $\mathrm{WBEH}_{\mathrm{t}}$ (before rounding)' is presented in Table 3 for informational purposes only and is not included in model estimation.
} 
more appropriate than the more traditional regression techniques.

The ordered Logit model assumes that underlying the ordinal responses given by those surveyed is a latent continuous variable. Accordingly, 'thresholds' are needed to partition this measure into several regions that correspond to the original ordinal categories of the survey. Therefore in the case of the CBQ, where all data were measured on a scale of 1 to 5 , the thresholds are 1-2, 2-3, 3-4 and 4-5. When the ordered Logit model is estimated, one observes parameter estimates for each independent variable at each threshold and a single set of diagnostics for the model as a whole. In the case of this study, the Likelihood Ratio, the McFadden $\mathrm{R}^{2}$ and the $\%$ Correct are reported for the model.

Pearson correlation coefficients (untabulated) revealed that multicollinearity between $\mathrm{REL}_{t}$ and IDEAL $\mathrm{t}_{\mathrm{t}}$ is present therefore, three estimations of the model were undertaken: the first includes both $\mathrm{REL}_{t}$ and $\mathrm{IDEAL}_{\mathrm{t}}$ (Table 4); the second REL $\mathrm{L}_{\mathrm{t}}$ only (Table 5); and the third IDEAL $_{t}$ only (Table 6). Individual model estimations allow for the robustness of findings to be tested by triangulating the results.

The results in Table 4 report that GENDER $\mathrm{t}_{\mathrm{t}}$ is positively and significantly correlated with $\mathrm{WBEH}_{\mathrm{t}}$ at the $1 \%$ level of significance. This result leads to the rejection of hypothesis 1 and suggests that female undergraduate accounting students are significantly more intolerant of academic cheating behavior than their male counterparts. This finding provides contemporary support for the gender socialization theory. Further findings in Table 4 indicate no association between $\mathrm{WBEH}_{\mathrm{t}}$ and $\mathrm{REL}_{\mathrm{t}}$. In contrast, IDEAL $\mathrm{L}_{\mathrm{t}}$ is marginally associated with $\mathrm{WBEH}_{\mathrm{t}}$ at the highest threshold of the dependent variable. These results indicate that students with the greatest intolerance of academic cheating tend to be more idealistic while relativism appears to have no bearing on students' intolerance of cheating behavior. Consequently, hypothesis 2 is rejected while hypothesis 3 is marginally supported by these findings. With respect to the control variables, Table 4 reports a negative association between 
Table 4

Estimation Results for Main Model

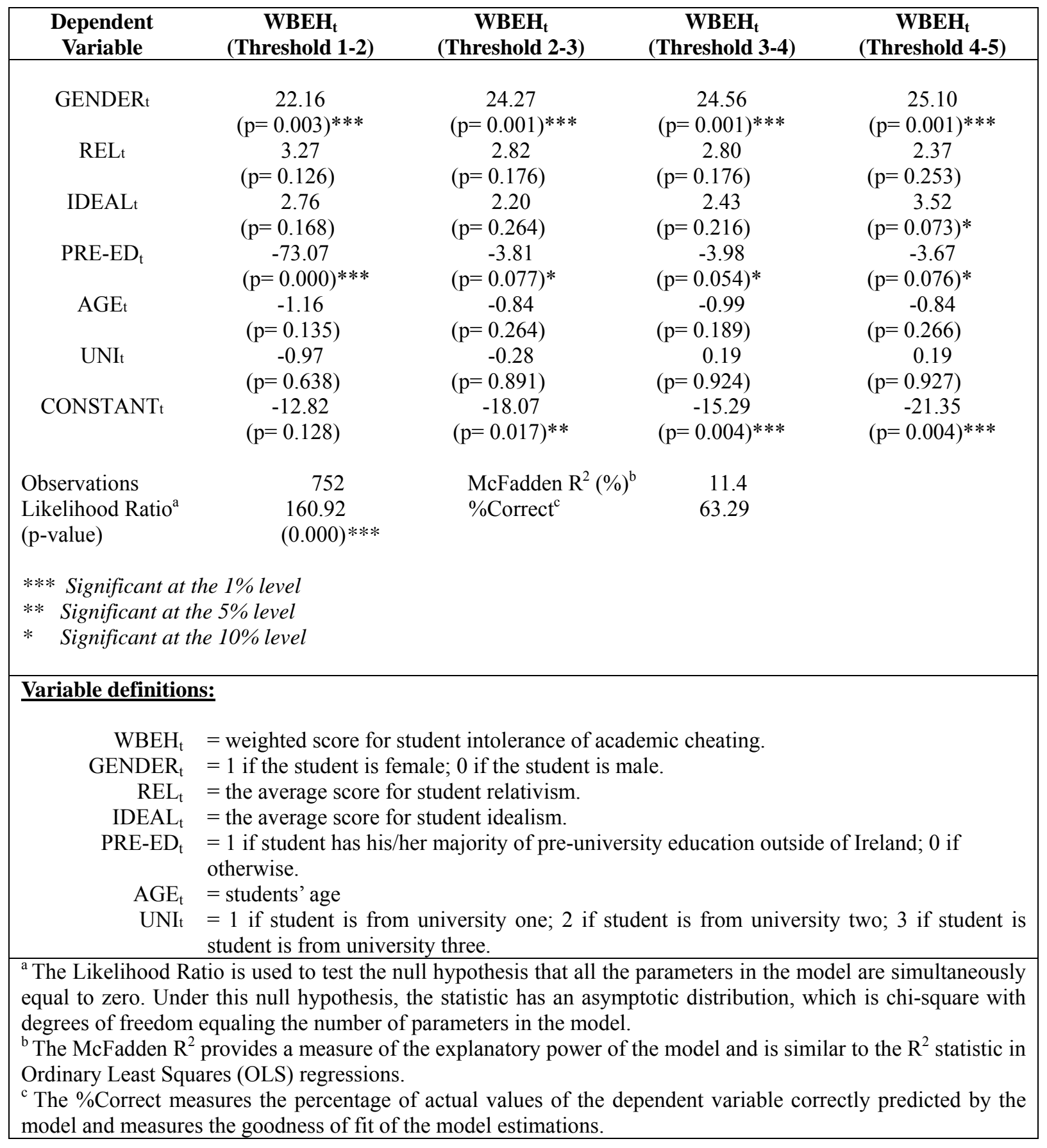

PRE-ED $\mathrm{t}_{\mathrm{t}}$ and $\mathrm{WBEH}_{\mathrm{t}}$ indicating that international students in the sample have a higher tolerance of academic cheating than their 'home' counterparts. This offers some additional exploratory insight into the varying nature of students' intolerances of cheating. However, while a range of reasons for this association may be suggested, these are not explored further here given the relatively small number of international students included in the study. 
In terms of the overall model, while a significant Likelihood Ratio and quite low McFadden $\mathrm{R}^{2}$ are reported, it is encouraging to observe that the model is correctly predicting over $63 \%$ of $\mathrm{WBEH}_{\mathrm{t}}$.

Table 5

Estimation Results for Main Model (Relativism only)

\begin{tabular}{|c|c|c|c|c|}
\hline $\begin{array}{l}\text { Dependent } \\
\text { Variable }\end{array}$ & $\begin{array}{c}\text { WBEH }_{\mathrm{t}} \\
\text { (Threshold 1-2) }\end{array}$ & $\begin{array}{c}\text { WBEH }_{\mathrm{t}} \\
\text { (Threshold 2-3) }\end{array}$ & $\begin{array}{c}\text { WBEH }_{\mathrm{t}} \\
\text { (Threshold 3-4) }\end{array}$ & $\begin{array}{c}\text { WBEH }_{\mathrm{t}} \\
\text { (Threshold 4-5) }\end{array}$ \\
\hline GENDER $\mathrm{t}$ & $\begin{array}{c}23.72 \\
(\mathrm{p}=0.000)^{* * *}\end{array}$ & $\begin{array}{c}25.60 \\
(p=0.000)^{* * *}\end{array}$ & $\begin{array}{c}26.00 \\
(\mathrm{p}=0.000)^{* * *}\end{array}$ & $\begin{array}{c}26.85 \\
(\mathrm{p}=0.000)^{* * *}\end{array}$ \\
\hline RELt & $\begin{array}{c}2.87 \\
(p=0.100)\end{array}$ & $\begin{array}{c}2.33 \\
(\mathrm{p}=0.168)\end{array}$ & $\begin{array}{c}2.37 \\
(p=0.156)\end{array}$ & $\begin{array}{c}2.21 \\
(p=0.186)\end{array}$ \\
\hline PRE-ED $_{t}$ & $\begin{array}{c}-64.83 \\
(\mathrm{p}=0.000)^{* * *}\end{array}$ & $\begin{aligned} & -5.17 \\
(\mathrm{p}= & 0.023)^{* *}\end{aligned}$ & $\begin{array}{c}-5.38 \\
(\mathrm{p}=0.014)^{* *}\end{array}$ & $\begin{array}{c}-5.21 \\
(\mathrm{p}=0.017)^{* *}\end{array}$ \\
\hline $\mathrm{AGE}_{\mathrm{t}}$ & $\begin{array}{c}-1.16 \\
(p=0.098)^{*}\end{array}$ & $\begin{array}{c}-0.83 \\
(p=0.222)\end{array}$ & $\begin{array}{c}-0.98 \\
(p=0.148)\end{array}$ & $\begin{array}{c}-0.84 \\
(p=0.210)\end{array}$ \\
\hline UNIt & $\begin{array}{c}0.77 \\
(\mathrm{p}=0.680)\end{array}$ & $\begin{array}{c}1.41 \\
(p=0.443)\end{array}$ & $\begin{array}{c}1.91 \\
(p=0.296)\end{array}$ & $\begin{array}{c}2.00 \\
(\mathrm{p}=0.273)\end{array}$ \\
\hline CONSTANT $_{t}$ & $\begin{array}{c}-7.08 \\
(p=0.346)\end{array}$ & $\begin{array}{c}-13.96 \\
(p=0.035)^{* *}\end{array}$ & $\begin{array}{c}-10.73 \\
(p=0.094)^{*}\end{array}$ & $\begin{array}{c}-13.71 \\
(\mathrm{p}=0.032)^{* *}\end{array}$ \\
\hline $\begin{array}{l}\text { Observations } \\
\text { Likelihood Ratio } \\
\text { (p-value) }\end{array}$ & $\begin{array}{c}752 \\
98.18 \\
(0.000)^{* * *}\end{array}$ & $\begin{array}{l}\text { McFadden } \mathrm{R}^{2}(\%) \\
\% \text { Correct }\end{array}$ & $\begin{array}{r}6.94 \\
58.11\end{array}$ & \\
\hline \multicolumn{5}{|c|}{$\begin{array}{l}\text { *** Significant at the } 1 \% \text { level } \\
* * \quad \text { Significant at the } 5 \% \text { level } \\
* \quad \text { Significant at the } 10 \% \text { level }\end{array}$} \\
\hline
\end{tabular}

Given the potential for multicollinearity between $\mathrm{REL}_{\mathrm{t}}$ and $\mathrm{IDEAL}_{\mathrm{t}}$, the main model was estimated using both of these variables independently. First, when IDEAL $\mathrm{L}_{t}$ is excluded from the model (see Table 5), the results are consistent with those reported in Table 4 namely no significant association is found between $\mathrm{WBEH}_{\mathrm{t}}$ and $\mathrm{REL}_{\mathrm{t}}$, again leading to the rejection of hypothesis 2. Secondly, when $\mathrm{REL}_{\mathrm{t}}$ is excluded from the model (see Table 6), IDEAL $\mathrm{t}_{\mathrm{t}}$ is found to be significantly associated (at 5\%) with $\mathrm{WBEH}_{\mathrm{t}}$ at the highest threshold. This confirms and strengthens the findings in Table 4 with respect to IDEAL $L_{t}$ and leads to the acceptance of hypothesis 3. Finally, with respect to GENDER $_{t}$, the findings reported in Tables 5 and 6 provide additional support for those of Table 4, namely that a consistently 
positive and significant association is found between GENDER $_{t}$ and $\mathrm{WBEH}_{t}$. As a consequence, hypothesis 1 is rejected. Regarding the control variables, a negative and significant correlation between $\mathrm{PRE}^{-\mathrm{ED}_{\mathrm{t}}}$ and $\mathrm{WBEH}_{\mathrm{t}}$ is again reported.

\section{Table 6}

\section{Estimation Results for Main Model (Idealism only)}

\begin{tabular}{|c|c|c|c|c|}
\hline $\begin{array}{l}\text { Dependent } \\
\text { Variable }\end{array}$ & $\begin{array}{c}\text { WBEH }_{t} \\
\text { (Threshold 1-2) }\end{array}$ & $\begin{array}{c}\text { WBEH }_{\mathrm{t}} \\
\text { (Threshold 2-3) }\end{array}$ & $\begin{array}{c}\text { WBEH }_{\mathrm{t}} \\
\text { (Threshold 3-4) }\end{array}$ & $\begin{array}{c}\text { WBEH }_{\mathrm{t}} \\
\text { (Threshold 4-5) }\end{array}$ \\
\hline IDEALt & $\begin{array}{c}2.40 \\
(p=0.099) *\end{array}$ & $\begin{array}{c}1.63 \\
(p=0.246)\end{array}$ & $\begin{array}{c}1.86 \\
(\mathrm{p}=0.182)\end{array}$ & $\begin{array}{c}2.86 \\
(\mathrm{p}=0.041)^{* *}\end{array}$ \\
\hline GENDER $_{t}$ & $\begin{array}{c}22.59 \\
(\mathrm{p}=0.000)^{* * *}\end{array}$ & $\begin{array}{c}24.78 \\
(\mathrm{p}=0.000)^{* * *}\end{array}$ & $\begin{array}{c}25.07 \\
(\mathrm{p}=0.000)^{* * *}\end{array}$ & $\begin{array}{c}25.64 \\
(\mathrm{p}=0.000)^{* * * *}\end{array}$ \\
\hline PRE-ED ${ }_{t}$ & $\begin{array}{c}-64.09 \\
(\mathrm{p}=0.000)^{* * *}\end{array}$ & $\begin{array}{c}-3.91 \\
(p=0.042) * *\end{array}$ & $\begin{array}{c}-4.06 \\
(p=0.026)^{* *}\end{array}$ & $\begin{array}{c}-3.79 \\
(p=0.038) * *\end{array}$ \\
\hline $\mathrm{AGE}_{\mathrm{t}}$ & $\begin{array}{c}-1.02 \\
(p=0.105)\end{array}$ & $\begin{array}{c}-0.68 \\
(p=0.255)\end{array}$ & $\begin{array}{c}-0.83 \\
(p=0.165)\end{array}$ & $\begin{array}{c}-0.67 \\
(p=0.260)\end{array}$ \\
\hline UNIt & $\begin{array}{c}-0.77 \\
(p=0.621)\end{array}$ & $\begin{array}{c}-0.05 \\
(p=0.975)\end{array}$ & $\begin{array}{c}0.42 \\
(p=0.780)\end{array}$ & $\begin{array}{c}0.43 \\
(p=0.776)\end{array}$ \\
\hline CONSTANT $_{\mathrm{t}}$ & $\begin{array}{c}-5.26 \\
(p=0.478)\end{array}$ & $\begin{array}{c}-11.85 \\
(p=0.069)^{*}\end{array}$ & $\begin{array}{c}-9.12 \\
(p=0.148)\end{array}$ & $\begin{array}{c}-16.50 \\
(\mathrm{p}=0.009) * * *\end{array}$ \\
\hline $\begin{array}{l}\text { Observations } \\
\text { Likelihood Ratio } \\
\text { (p-value) }\end{array}$ & $\begin{array}{c}752 \\
150.03 \\
(0.000) * * *\end{array}$ & $\begin{array}{l}\text { McFadden } \mathrm{R}^{2}(\%) \\
\% \text { Correct }\end{array}$ & $\begin{array}{l}10.62 \\
61.57\end{array}$ & \\
\hline $\begin{array}{l}* * * \text { Significant a } \\
* * \quad \text { Significant at } \\
* \quad \text { Significant at }\end{array}$ & $\begin{array}{l}1 \% \text { level } \\
5 \% \text { level } \\
10 \% \text { level }\end{array}$ & & & \\
\hline
\end{tabular}

The McFadden $\mathrm{R}^{2}$ and the \%Correct reported in Tables 5 and 6 confirm that idealism is a better explanator of cheating intolerance than relativism. Indeed, the results of these two statistics with respect to idealism compare favorably with those reported for the main model (Table 4).

\subsection{Robustness tests}

To assess the robustness of findings, additional tests were conducted. Clearly the value of the dependent variable, $\mathrm{WBEH}_{\mathrm{t}}$, is determined by the weightings applied to the ten cheating 
behaviours which comprise the CBQ. Consequently the authors applied a suite of alternative weightings, ranging from a simple mean across all CBQ questions to a weighting which reflected the number of questions in the CBQ pertaining to examinations, continuous assessment and other aspects of academic dishonesty. Findings from this untabulated analysis were consistent with those reported above.

A second sensitivity test involved re-estimating the research model excluding each control variable was carried out to corroborate the main results reported in Tables 4, 5 and 6 . While there are numerous iterations of the model when conducting such further tests, results from these untabulated results support all main findings reported in Tables 4 to 6 , namely that gender and idealism are positively and significantly correlated with the dependent measure of cheating behavior.

Finally, as an additional means of corroborating the findings with respect to both relativism and idealism, alternative measures were developed and applied in the model estimations. Since multicollinearity between relativism and idealism is present, purer measures of both sub-scales can be derived by regressing each measure on the other. The residuals of such estimations may be seen as 'pure' measures of relativism and idealism, and are more formally stated as:

$$
\begin{aligned}
& \text { REL }_{\mathrm{t}}=\alpha_{0}+\alpha_{1} \text { DEAL }_{\mathrm{t}}+\varepsilon_{\mathrm{t}} \quad\left[\varepsilon_{\mathrm{t}}=\text { Pure Relativsm }\left(\text { PUREREL }_{\mathrm{t}}\right)\right] \\
& \text { IDEAL }_{\mathrm{t}}=\alpha_{0}+\alpha_{1} \mathrm{REL}_{\mathrm{t}}+\varepsilon_{\mathrm{t}} \quad\left[\varepsilon_{\mathrm{t}}=\text { Pure Idealism }\left(\text { PUREIDEAL }_{\mathrm{t}}\right)\right]
\end{aligned}
$$

Both PUREREL $\mathrm{P}_{\mathrm{t}}$ and PUREIDEAL $\mathrm{P}_{\mathrm{t}}$ were replaced in model estimations. Untabulated results from this analysis yield the same results as those reported above, thus providing further support for the findings with respect to relativism and idealism as reported in Tables 4 to 6 . 


\section{Discussion and Conclusions}

The current study reports that Irish accounting undergraduate students, the majority of whom proceed to a career in accountancy, are fairly intolerant of academic cheating behavior. This finding is encouraging from two perspectives. First, it augurs well for the students' immediate academic careers. Despite the fact that a recession-hit world has created greater career uncertainty for students, cheating does not appear to be an acceptable way of achieving academic success. Secondly, when one considers the premise that the academic integrity and honesty demonstrated at undergraduate level is a strong predictor of workplace ethical behavior, these findings provide a degree of reassurance regarding the future moral direction of the Irish accounting profession. Bearing in mind that many of these accounting graduates progress to become the Irish accounting professionals of the future ${ }^{4}$, the basic assertion which emanates from these findings is that the continuation of these attitudes through to the workplace may make a positive contribution to restoring public confidence to an Irish business world which has been seriously undermined by recent financial scandals.

In an effort to establish why some individuals are more intolerant of cheating behavior than others, the study considered three possible determinants, namely gender, relativism and idealism. First, gender was found to be significantly associated with undergraduate accounting students' intolerance of cheating behavior with females having a more ethical attitude to classroom cheating than their male counterparts. While Pierce and Sweeney (2010) also reported a stricter position among Irish female accounting trainees with respect to ethical judgment, their findings were less conclusive in that significance was reported in only one of the four scenarios tested. Therefore the findings of the current study with respect to

\footnotetext{
${ }^{4}$ The vast majority of students who study accounting at university level go on to become Irish chartered accountants. For example, 84\% of entrants to Chartered Accountants Ireland in 2012 held a relevant accounting degree (Irish Auditing and Accounting Supervisory Authority, 2012, p.22).
} 
gender ethics not only corroborate but also strengthen those reported by Pierce and Sweeney (2010). Given the relatively equal representation of males and females in Irish accounting programs where women share so many educational and training experiences with their male counterparts, one may have expected some degree of equalization in the ethical judgment of both sexes. However, this was not found to be the case. Instead, the current study confirms that gender differences in ethical attitude still appear to be relevant. To this end, given the increasing female representation in the profession, the conclusion to be drawn from these findings echoes that of Ameen et al. (1996), published some time ago, that 'the influx of female accountants could have a positive effect on the business community' (Ameen et al., 1996, p.596). More specifically, in the context of the current study, the findings with respect to gender may go some way to providing a positive influence on the ethical judgment of future accountants and enable the Chartered Accountants Ireland to achieve its strategic objective of rebuilding trust in the Irish accountancy profession.

This multi-campus study also considered the impact of idealism and relativism on intolerance of academic cheating behavior. The findings with respect to these two variables were in marked contrast to one another. Idealism was found to be significantly associated with greater levels of intolerance of academic cheating behavior among accounting students. However, no significant association between relativism and intolerance of academic cheating was found at any level. This would suggest that, in the context of academic cheating, being an idealist is more desirable than being a relativist. These findings confirm those reported by Sierra and Hyman (2008) who suggested that idealism among students is to be encouraged and fostered as a bulwark to cheating behavior in the classroom. To this end, they recommended that "instructors should try to minimize ethical relativism among students" (p.62) and promote idealism. The expectation is that this focus on idealism should, in turn, reduce the likelihood of unethical behavior in the workplace. Indeed, prior research has 
reported that it is possible to influence an individual's personal moral philosophy. For example, Coyne, Massey and Thibodeau (2005) and Massey and Van Hise (2009) found that, following an educational intervention, business studies and accounting students exhibited a reduction in relativism and an increase in idealism scores. The expectation is that, if individuals comprehend their ethical philosophy more fully prior to leaving higher education, they will be better equipped to contend with the ethical decisions they may encounter throughout their careers (Caldwell, Karri \& Matula, 2005). With appropriate direction and guidance from educators, students could be presented with ethical dilemmas and be introduced to alternative ethical perspectives which stimulate discussion and promote reflection on each other's moral position. While it is accepted that no amount of ethics education will ever change the ethical attitude of the most 'egregious violators' (Adams, Tashchian \& Shore, 1999, p. 243), nevertheless, making students aware of alternative ethical perspectives should, at some level, encourage some of them to take the moral consequences of their actions into account in ways they previously would not have considered. By so doing, it is anticipated that undergraduate students will be provided with a more rounded moral perspective which encourages idealism and thereby serves them well in their working lives. The business world is ill-served by recruiting graduates who possess a set of dubious moral values. As gatekeepers of a respected profession (Saunders, 1993), accounting academics have a role to play in shaping the ethical ideology of those entering the workforce by providing some measure of moral direction. This direction, combined with the increased focus on the importance of ethical standards within professional accountancy training should hopefully go some way to restoring faith in the tarnished reputation of the accounting profession in Ireland.

The findings of this study should be interpreted in the light of the following limitations. First, attitudinal data were collected using questionnaires completed by undergraduate 
students in a classroom environment. However, what individuals say and what they do may not be one and the same. Whilst attitudinal data serves as a reasonable proxy for actual behavior, further research in this area might consider the use of experimental methodologies which aim to bridge the gap between what students say they do and what they actually do. For example, Roig (1997) and Rettinger, Jordan and Peschiera (2004) have reported on the use of scenarios and experimental vignette methods when exploring one aspect of academic dishonesty, namely plagiarism. Additionally, more recently educational technology has been employed to directly observe cheating behaviors in the case of plagiarized materials (see for example, Keck, 2006; Ledwith \& Risquez, 2008). Secondly, the present study has not considered other possible determinants of cheating behavior including, for example religiosity and culture. With respect to religiosity, it was not possible to consider the impact of this variable due to the restrictions imposed by the three ethics committees who regarded this information to be sensitive. Further, due to the small number of international students in the sample, the impact of culture could not be adequately explored. Future research might investigate these determinants and others in the context of classroom cheating behaviors and the implications for workplace ethics. 


\section{References}

Adams, J., Tashchian, A., \& Shore, T.H. (1999). Frequency, recall and usefulness of undergraduate ethics education. Teaching Business Ethics, 3(3), 241-253.

Allmon, D.E., Page, D., \& Robert, R. (2000). Determinants of perceptions of cheating: ethical orientation, personality and demographics. Journal of Business Ethics, 23(4), 411422.

Ameen, E., Guffey, D.M. \& McMillan, J.J. (1996). Gender differences in determining the ethical sensitivity of future accounting professionals. Journal of Business Ethics, 15(5), 591-597.

Barnett, T., Bass, K., \& Brown, G. (1994). Ethical ideology and ethical judgment regarding ethical issues in business. Journal of Business Ethics, 13(6), 469-480.

Barnett, T., Bass, K., \& Brown, G. (1996). Religiosity, ethical ideology, and intentions to report a peer's wrongdoing. Journal of Business Ethics, 15(11), 1161-1171.

Betz, M., O’Connell, L., \& Shepard, J.M. (1989). Gender differences in proclivity for unethical behavior. Journal of Business Ethics, 8(5), 321-324.

Beu, D., Buckley, S.M.R., \& Harvey, M.G. (2003). Ethical decision-making: a multidimensional construct. Business Ethics: A European Review, 12(1), 88-107.

Bowers, W. (1964). Student dishonesty and its control in college. New York: Columbia University, Bureau of Applied Social Research.

Caldwell, C., Karri, R., \& Matula, T. (2005). Practicing what we teach - Ethical considerations for business schools. Journal of Academic Ethics, 3(1), 1-25.

Chan, S.Y.S. \& Leung, P. (2006). The effects of accounting students' ethical reasoning and personal factors on their ethical sensitivity. Managerial Auditing Journal. 21(4), 436-475.

Coyne, M., Massey, D., \& Thibodeau, J. (2005). Raising students' ethical sensitivity with a value relevance approach. In B.N. Schwartz and J.E. Ketz (Eds.), Advances in Accounting 
Education: Teaching and Curriculum Innovations, Volume 7, (pp. 171-205). San Diego, US: Elsevier.

Davis, M.A., Anderson, M.G., \& Curtis, M.B. (2001). Measuring ethical ideology in business ethics: A critical analysis of the Ethics Position Questionnaire. Journal of Business Ethics, 32(1), 35-53.

Davis, J.R. \& Welton, R.E. (1991). Professional Ethics: Business Students' Perceptions. Journal of Business Ethics, 10(6), 451-463.

Ferrell, O.C. \& Weaver, K.M. (1978). Ethical beliefs of marketing managers. Journal of Marketing, 42(July), 69-73.

Financial Reporting Council. (2013). Key Facts and Trends in the Accountancy Profession, London: Financial Reporting Council.

Flood, B., \& Wilson, R.M.S. (2008). An exploration of learning approaches of prospective professional accountants in Ireland. Accounting Forum, 32(3), 225-239.

Forrest, P., \& Pritchett, T.K. (1990). Business students' perceptions of ethics in the classroom. Journal of Midwest Marketing, 5(Spring), 117-124.

Forsyth, D.R. (1980). A taxonomy of ethical ideologies. Journal of Personality and Social Pychology, 39(1), 175-184.

Forsyth, D. R. (1992). Judging the Morality of Business Practices: The Influence of Personal Moral Philosophies. Journal of Business Ethics, 11(5-6), 461-470.

Forsyth, D.R., \& Berger, R.E. (1982). The effects of ethical ideology on moral behavior. Journal of Social Psychology, 117(1), 53-56.

Franklyn-Stokes, A., \& Newstead, S.E. (1995). Undergraduate cheating: who does what and why? Studies in Higher Education, 20(2), 159-172.

Gilligan, C. (1982). In a different voice. Cambridge, MA: Harvard University Press.

Granitz, N. \& Loewy, D. (2007). Applying ethical theories: interpreting and responding 
to student plagiarism. Journal of Business Ethics, 72(3), 293-306.

Greene, W. H. (2011) Econometric Analysis, $7^{\text {th }}$ Edition, Pearson Prentice Hall, New York.

Irish Auditing and Accounting Supervisory Authority (IAASA), Údarás Maoirseachta Iniúchta agus Cuntasaíochta na hÉireann. (2012). Profile of the Profession, Kildare, Ireland: IAASA.

Jones, R.C., Hamilton, K.L., \& Ingram, R. (2007). Students' perception of ethical classroom behaviour: a closer look. Journal of Business, Industry and Economics, 8(1), 3955.

Keck, C. (2006). The use of paraphrase in summary writing: a comparison of L1 and L2 writers. Journal of Second Language Writing, 15(4), 261-278.

Kidwell, L.A., \& Kent, J. (2008). Integrity at a distance: a study of academic misconduct among university students on and off campus. Accounting Education: an international journal, 17(Supplement S3-S16), 3-16.

Ledwith, A. \& Risquez, A. (2008). Using anti-plagiarism software to promote academic honesty in the context of peer reviewed assignments Studies in Higher Education, 33(4), 4 $371-384$.

Massey, D., \& Van Hise, J. (2009). Walking the walk: Integrating lessons from multiple perspectives in the development of an accounting ethics capstone. Issues in Accounting Education, 24(4), 481-510.

McCabe, A.C., Ingram, R., \& Dato-on, M.C. (2006). The business of ethics and gender. Journal of Business Ethics, 64(2), 101-116.

McCabe, D.L., \& Bowers, W.J. (1994). Academic dishonesty among males in college: a thirty year perspective. Journal of College Student Development, 35(1), 5-10. 
McCabe, D.L., \& Treviño, L.K. (1993). Academic dishonesty: honor codes and other contextual influences. Journal of Higher Education, 64(5), 522-538.

McCabe, D.L., Butterfield, K.D. \& Trevino, L.K. (2006). Academic Dishonesty in Graduate Business Programs: Prevalence, Causes, and Proposed Action. Academy of Management Learning and Education, 5(3), 294-305.

Newstead, S.E., Franklyn-Stokes, A., \& Armstead, P. (1996). Individual differences in student cheating. Journal of Educational Psychology, 88(2), 229-241.

Nonis, S., \& Swift, C.O. (2001). An examination of the relationship between academic dishonesty and workplace dishonesty: a multicampus investigation. Journal of Education for Business, 77(2), 69-77.

Norton, L.S., Tilley, A.J., Newstead, S.E., \& Franklyn-Stokes, A. (2001). The pressures of assessment in undergraduate courses and their effect on student behaviours. Assessment \& Evaluation in Higher Education, 26(3), 269-284.

O’Carroll, L. (2010). Former Irish Nationwide boss Michael Fingleton still hasn’t paid bonus back, The Guardian: http://www.guardian.co.uk/business/ireland-business-blog-withlisa-ocarroll/2010/dec/23/irish-nationwide-michael-fingleton-bonus

Pierce, B. \& Sweeney, B. (2010). The relationship between demographic variable and ethical decision making of trainee accountants. International Journal of Auditing, 14(1), 7999.

Pratt, C., \& McLaughlin, G. (1989). An analysis of predictors of students' ethical inclinations. Research in Higher Education, 30(2), 195-219.

Radtke, R.R. (2000). The Effects of Gender and Setting on Accountants' Ethically Sensitive Decisions. Journal of Business Ethics, 24(4), 299-312.

Rettinger, D.A., Jordan, A.E., \& Peschiera, F. (2004). Evaluating the motivation of other students to cheat: A vignette experiment. Research in Higher Education, 45(8), 873-890. 
Risquez, A., O'Dwyer, M. \& Ledwith, A. (2011). Technology enhanced learning and plagiarism in entrepreneurship education. Education and Training, 53(8), 750-761.

Robinson, S.L., \& Bennett, R.J. (1995). A typology of deviant workplace behaviors: a multidimensional scaling study. Academy of Management Journal, 38(2), 555-572.

Roig, M. (1997). Can undergraduate students determine whether text has been plagiarized? Psychological Record, 47(1), 113-123.

Ryan, C. (2011). The euro crisis and crisis management: big lessons from a small island. International Economics and Economic, Policy, 8(1), 31-43.

Saunders, E.J. (1993). Confronting academic dishonesty. Journal of Social Work Education, 29(2), 224-230.

Schlenker, B. R. \& Forsyth, D.R. (1977). On the ethics of psychological research. Journal of Experimental Social Psychology, 13, 369-396.

Sierra, J.J. \& Hyman, M.R. (2008). Ethical Antecedents of Cheating Intentions: Evidence of Mediation, Journal of Academic Ethics, 6(1), 51-66.

Sikula, A. Sr., \& Costa, A.D. (1994). Are women more ethical than men? Journal of Business Ethics, 13(11), 859-871.

Simkin, M., \& McLeod, A. (2010). Why do college students cheat? Journal of Business Ethics, 94(3), 441-453.

Stanga, K.G. \& Turpen, R.A. (1991). Ethical judgements on selected accounting issues: an empirical study. Journal of Business Ethics, 10(10), 739-747.

Steiner, G. A. \& Steiner, J. F. (2011). Business, Government and Society: a Managerial Perspective. New York, NY:McGraw-Hill

Terpstra, D.E., Rozelle, E.J., \& Robinson, R.K. (1993). The Influence of Personality and Demographic Variables on Ethical Decisions Related to Insider Trading. The Journal of Psychology: Interdisciplinary and Applied, 127(4), 375-389. 